\title{
$\mathrm{Cr}_{2} \mathrm{O}_{3}-\mathrm{TiO}_{2}$ 系における高指数結晶学的シェア相の 透過型電子顕微鏡観察
}

\author{
神谷純生・吉村昌弘・宗宮重行 \\ （東京工業大学 工業材料研究所）
}

$\mathrm{C}_{2} \mathrm{O}_{3}-\mathrm{TiO}_{2}$ 系に存在する高指数 $\mathrm{CS}$ 相を透過型電子顕微鏡によって観察した. $1390^{\circ} \mathrm{C}, \mathrm{Cr}_{2} \mathrm{O}_{3}$ 13.7 24.1 wt\% 組成領域において高指数 CS 面の方位は $\mathrm{Cr}_{2} \mathrm{O}_{3}$ 量の減少とともに (121) $\mathrm{r}$ ( $\mathrm{r}$ は ルチル副格子を示す $)$ より $(5,12,7)_{\mathrm{r}}$ まで変化し，それに伴い CS 面の間隔は $12.9 \AA$ より 18.2 $\AA$ へと增加した. $\mathrm{Cr}_{2} \mathrm{O}_{3}$ 7.5 13.7 wt \% 組成領域では $(5,12,7)_{\mathrm{r}} \mathrm{CS}$ 相はルチル固溶体と共存し, また $(121)_{\mathrm{r}} \mathrm{CS}$ 相の上端成分はこれ⿱でX線的にその存在が考えられていた $n=9\left(\mathrm{Cr}_{2} \mathrm{Ti}_{7} \mathrm{O}_{17}\right)$ で はなく, $n=8\left(\mathrm{Cr}_{2} \mathrm{Ti}_{6} \mathrm{O}_{15}\right)$ であった。一定組成試料において，個々の結晶片によって，CS 相の構 造は，わずかずつ異なるものも検出され，通常単一の CS 相からなる均質なバルク試料を得ること は困難であった。しかし個々の結晶片は観察視野内で等間隔に配列する CS 面を含み，ほぼ均質な 構造を有していた。 またルチル構造を母体にした結晶学的シェア操作を基本にして, 高指数 CS 面 の構造モデルを考察した結果， $(5,12,7)_{\mathrm{r}} \mathrm{CS}$ 面は直線状ではなく，むしろ CS 面に沿って折れ曲 がった構造であることが示唆された.

(1980 年 7 月 16 日受付)

\section{Electron Microscopic Observations for the High-index Crystallographic Shear Phases in the System $\mathrm{Cr}_{2} \mathrm{O}_{3}-\mathrm{TiO}_{2}$}

\author{
Sumio KAMIYA, Masahiro YOSHIMURA and Shigeyuki SŌMIYA \\ (Research Laboratory of Engineering Materials, Tokyo Institute of Technology) \\ 4259, Nagatsuta, Midori-ku, Yokohama-shi 227
}

\begin{abstract}
Electron diffraction and lattice image observations have been applied to study the high-index crystallographic shear (CS) phases derived from rutile-type structure in the system $\mathrm{Cr}_{2} \mathrm{O}_{3}-$ $\mathrm{TiO}_{2}$. At $1390^{\circ} \mathrm{C}$, there existed many CS phases where the orientation of the CS planes continuously changed from $(121)_{\mathrm{r}}$ to $(5,12,7)_{\mathrm{r}}$ and the spacing of CS planes increased from $12.9 \AA$ to $18.2 \AA$ according to the decrease of $\mathrm{Cr}_{2} \mathrm{O}_{3}$ contents in the range of $13.7 \sim 24.1 \mathrm{wt} \%$ $\mathrm{Cr}_{2} \mathrm{O}_{3}$. The high-index $(5,12,7)_{\mathrm{r}} \mathrm{CS}$ phase coexisted with rutile solid solution in the range of 7.5 13.7 wt $\% \mathrm{Cr}_{2} \mathrm{O}_{3}$. The highest end member of $(121)_{\mathrm{r}} \mathrm{CS}$ phase appeared to be $\mathrm{Cr}_{2} \mathrm{Ti}_{6} \mathrm{O}_{15}$ instead of $\mathrm{Cr}_{2} \mathrm{Ti}_{7} \mathrm{O}_{17}$ which was previously regarded as a member of $(121)_{\mathrm{r}} \mathrm{CS}$ phase by X-ray diffraction analysis. The crystals had ordered features with equal spaced CS planes within each fragment, whereas the structures of high-index CS phases were slightly different from one fragment to another obtained from a bulk specimen with constant composition.

The structural model for $(5,12,7)_{\mathrm{r}}$ CS plane was presented on the basis of the structural units for $(011)_{\mathrm{r}}$ and $(121)_{\mathrm{r}}$ boundaries and it seemed that $(5,12,7)_{\mathrm{r}}$ CS plane had zig-zag feature rather than straight line along CS plane.

[Received July 16, 1980]
\end{abstract}

Key-words : $\mathrm{Cr}_{2} \mathrm{O}_{3}-\mathrm{TiO}_{2}$, Shear structure, Crystallographic shear, Phase relations

\section{1. 緒言}

既に著者らは $\mathrm{Cr}_{2} \mathrm{O}_{3}-\mathrm{TiO}_{2}$ 系の空気中 $1250^{\circ} \sim 1765^{\circ} \mathrm{C}$ における相関係を明らかにし，系内には一般式が $\mathrm{Cr}_{2} \mathrm{Ti}_{n-2} \mathrm{O}_{2 n-1}(n=6,7,8)$ で示される同族系列酸化物の
存在することを確認するとともに，それらの安定温度領 域を決定した ${ }^{1) ~ 3)}$. 更に透過型電子顕微鏡観察によって これらの同族系列酸化物がルチルの (121) 面に平行な結 晶学的シェア (CS) 面を有する (121) r CS 相であるこ 
とを示した4)。一方，ルチル固溶体と (121) $\mathrm{r}$ CS 相との 間には一連の相が存在し，それらのX線粉末回折図形に は超格子線と思われる多くの回折線が観察され，かつ回 折線の位置は $\mathrm{Cr}_{2} \mathrm{O}_{3}$ 量の変化とともに連続的に変化して いた。しかしながら，X線粉末回折法ではこれらの相の 構造，あるいは組成に対するわずかな構造の変化を詳細 に検出することは困難であった。これに対して制限視野 電子線回折法は, 通常の多結晶体試料からでもミクロン オーダーの個々の単結晶の回折像を得ることが可能であ るために，こうした相の解析に有力な手法となりうる.

$\mathrm{Gibb} ら^{5)}$ は $\mathrm{Cr}_{2} \mathrm{O}_{3}$ 1.9 24.1 wt\% の組成試料を $1300^{\circ} \mathrm{C}$ で加熱後, 空気中に取り出して冷却した試料を 透過型電子顕微鏡で観察した. その結果, $\mathrm{Cr}_{2} \mathrm{Ti}_{n-2} \mathrm{O}_{2 n-1}$ で示され， $n=8,9,10,11$ の (121) r CS 相及び (121) r と (132) $\mathrm{r}$ の中間の指数を有する CS 相が認められたと 報告した。一方，Philp ら ${ }^{6)}$ は $\mathrm{Cr}_{2} \mathrm{O}_{3} 1.9 \sim 21.7 \mathrm{wt} \%$ の組成試料を白金のカプセル中に封入して $1300^{\circ} \mathrm{C}$ で加 熱後, 空気中で泠却した試料を透過型電子顕微鏡で観察 し，(121) $)_{\mathrm{r}} \mathrm{CS}$ 相の上端成分は $n=11$ ではなく, $n=8$ であること，また $\mathrm{Cr}_{2} \mathrm{O}_{3}$ 量の減少とともに CS 面の方 位を (121) $\mathrm{r}$ から $(253)_{\mathrm{r}}$ へと変化させる高指数 CS 相 の存在することを明らかにした。同時に，(121） 以 以外の 高指数 CS 面は, Gibb らの用いた $[2 \overline{1} 0]_{\mathrm{r}},[\overline{1} 01]_{\mathrm{r}}$ 及び $[01 \overline{2}]_{\mathrm{r}}$ 晶帯中には存在しないため, 高指数 CS 相の構 造を検討する上で, $[1 \overline{1} 1]_{\mathrm{r}}$ 晶带からの電子線回折像が 不可欠であることを強調した.これらの高指数 CS 相は $\mathrm{Ti}-\mathrm{O}$ 系任存在する高指数 $\mathrm{CS}$ 相 ${ }^{7), 8)}$ と同樣の構造を有 し,一般式は $\mathrm{M}_{n} \mathrm{O}_{2 n-p}$ (M は金属, $n, p$ は整数), CS 面の指数は $(h k l)_{\mathrm{r}}=p(121)_{\mathrm{r}}+q(011)_{\mathrm{r}}(p, q$ は整数 $)$ で 示された. 種々の指数を有する CS 相が検出されてお り，陽イオンに対する陰イオンの組成比が変化するにつ れて, CS 面の方位が変化することから，これらの CS 面は “回転シェア面” (Swinging shear planes) ${ }^{9)}$, また こうした高指数 CS 相からなる一連の相は, “連続規則 固溶体相” (Continuous ordered solid solution) と称さ れている.

しかしながら，Gibb ら，あるいは Philp らの透過型 電子顕微鏡観察は主として $1300^{\circ} \mathrm{C}$ で加熱处理した試料 に対してなされたものであり，更に高温で処理した試料 の検討はなされていない．既に著者らのこれまでの相関 係の研究から, Philp らの報告した高指数 CS 相と思わ れる一連の相が, $1420^{\circ} \mathrm{C}$ までは安定に存在することが 明らかとなっているので，本研究では更に透過型電子顕 微鏡を用い， $1300^{\circ} \mathrm{C}$ 以上で加熱，急冷した試料を観察 した結果，高指数 CS 相に関して知見を得たので報告す る.

\section{2. 実 験 方 法}

\section{1 試 料 調 製}

出発物質は関東化学社製特級試薬アナターゼ型 $\mathrm{TiO}_{2}$ 及び $\mathrm{Cr}_{2} \mathrm{O}_{3}$ 酸化物粉末を用いた. 出発物質中に含をれ る水分その他の揮発成分を除去するために各酸化物を同 素地を敷いたアルミナるつぼ中で $600^{\circ} \mathrm{C}$ において 12 時 間仮焼後，室温まで泠却し $\mathrm{Cr}_{2} \mathrm{O}_{3} 7.5 \sim 24.1 \mathrm{wt} \%$ の種 々の組成比になるようにひょう量した，次に特級試薬の メタノールを用いてこれらの酸化物をめのう乳鉢中で数 時間混合し，乾燥させて粉末混合試料を得た。これを $200 \mathrm{MPa}$ の等方加圧成形法により $8 \mathrm{~mm} \phi \times 5 \mathrm{~mm}$ のペ レットとした. 加熱時におけるペレット表面からの $\mathrm{Cr}_{2} \mathrm{O}_{3}$ の蒸発に伴う組成の変化を避けるために, ペレッ 卜を白金のるつぼ中に入れ，更に周囲を同一組成の粉末 で包んだ。 $1390^{\circ} \mathrm{C}$ で 24 時間加熱後，るつぼを冷水中 一落下させ，試料を急冷した.

\section{$2.2 \mathrm{X}$ 線粉末回折法}

急冷した試料ペレットの表面を炭化ケイ素質研磨紙で 数 $\mathrm{mm}$ 除去し, 数分間ペレットを超音波洗浄した後, ペレットの中心部から採取した試料をめのら乳鉢中で粉 砕してX線粉末回折法の試料とした．X線粉末回折法に 㹥黒鉛分光結晶によって単色化した $\mathrm{Cu} \mathrm{K}_{\alpha}$ 線を用い, 回転対陰極型X線回折装置（理学電機社製 RU-200）を 使用した.

\section{3 透過型電子顕微鏡観察}

急冷した試料ペレットの中心部より採取した試料を特 級試薬のブタノールを用いてめのう乳鉢中で砕いて縣濁 液をつくり，これをマイクログリッドタを張った銅メッ シュ上に滴下し自然乾燥して観察用試料とした。観察に は傾斜装置を備えた日立製作所製 H-TEM 700 透過型 電子顕微鏡を用いた。薄片結晶の回折像を観察しなが ら，傾斜及び回転操作を行い，入射電子線と $[1 \overline{1} 1]_{\mathbf{r}}$ 晶 帯軸とが平行になった後，電子線回折像及び格子像を写 真撮影した.

\section{$2.4 \mathrm{CS}$ 面の指数 $(\boldsymbol{h} k \boldsymbol{l})_{\mathrm{r}}$ の決定}

ルチル構造から誘導される高指数 CS 相, $\mathrm{M}_{n} \mathrm{O}_{2 n-p}$ の CS 面の指数は $(h k l)_{\mathrm{r}}=p(121)_{\mathrm{r}}+q(011)_{\mathrm{r}}=(p, 2 p+$ $q, p+q)_{\mathrm{r}}$ で手えられ，これらの高指数 CS 面は $[1111]_{\mathrm{r}}$ 晶帯中に存在する．したがって高指数 CS 相の構造を検 討するためには， $[111]_{\mathrm{r}}$ 電子線回折像を得る必要があ る.これらの回折像において， $(h k l)_{\mathrm{r}} \mathrm{CS}$ 面はルチルの 逆格子ベクトル $g\left(h k l_{\mathrm{r}}\right)$ に沿った超格子スポットを与え るが，それらはルチルの副格子点近傍から遠ざかるにつ れて強度は減少し，すべてを観察することはできない。 そこで本研究では CS 面の指数堂決定するために, Philp らの用いた方法に従った。すなわ图 1 に示したように 逆格子ベクトル $g\left(h k l_{\mathrm{r}}\right)$ が $121_{\mathrm{r}}$ 及び $011_{\mathrm{r}}$ の各逆格子 点を結ぶ線分を内分する比 $p^{\prime}(=p / q=n / m)$ を実測し 


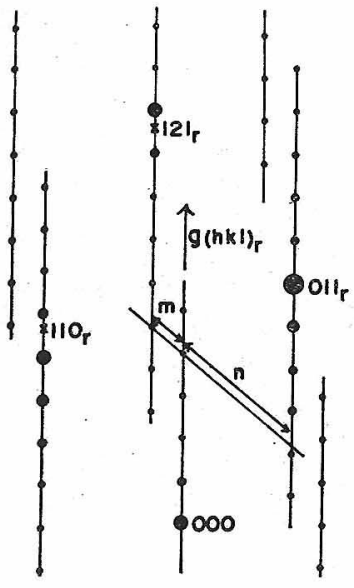

Fig. 1. Scherratic drawing of $[1 \overline{1} 1]_{\mathrm{r}}$ zone axis diffraction pattern after Philp et al. ${ }^{6)}$ The index of CS plaine is given by $(h k l)_{\mathrm{r}}=p(121)_{\mathrm{r}}$ $+q(011)_{\mathrm{r}}, p^{\prime}=p / q=$ $n / m$.
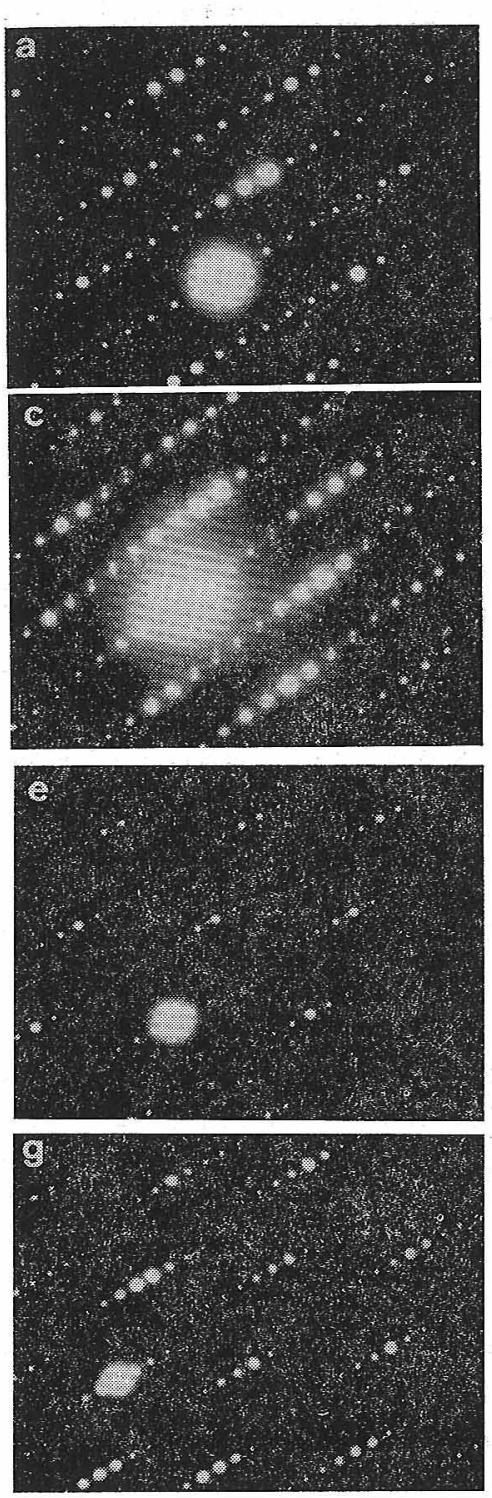

た. 内分比 $p^{\prime}$ の測定は得られた回折像を拡大して行い, 誤差は $p^{\prime}$ が 2.5〜10 に対して 3〜8\% であった.

\section{$2.5 \mathrm{M}_{n} \mathrm{O}_{2 n-p}$ における $n$ 值及び $\mathrm{CS}$ 面の閒隔} $D_{\mathrm{sp}}$ の測定

高指数 CS 相の $[1 \overline{1} 1]_{\mathrm{r}}$ 電子線回折像において，ルチ ル副格子の 011 反射は共通の強いスポットとして観察 される。一方, 著者らが既に報告したように (121) $)_{\mathbf{r}}$ CS 相である $\mathrm{Cr}_{2} \mathrm{Ti}_{n-2} \mathrm{O}_{2 n-1}(n=6,7,8)$ の $d_{100}$ を格子定数 上り求めるとそれぞれ，2.498 $(n=6), 2.498 \AA(n=$ 7) 及び $2.497 \AA(n=8)$ となり一定であっだ．(121）r CS 相の 100 反射はルチルの $011_{\mathrm{r}}$ 反射に等佑であるか

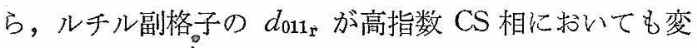
化しないと仮定するならば，Philp らが示したように “ $d_{011_{\mathrm{r}}}=2.498 \AA$ を内部標準として $g$ $\left(h k l_{\mathrm{r}}\right)$ に沿って橓接するスポット の閒隔を実測し, CS 面の間隔 $D_{\mathrm{sp}}$ を求めることが可能である。こうし て求めた $D_{\mathrm{sp}}$ 值の 測定誤差忙 $1 \%$ 以内であった．またルチル構造より 誘導される CS 相の構造モデルに従 えば, $D_{\mathrm{sp}}$ 值は $D_{\mathrm{sp}}=d_{k k l_{\mathrm{r}}} \times(n-\alpha)$ で与えられる。ここで $\alpha$ は CS 面 を生成させるための変位べクトル $1 / 2[0 \overline{1} 1]_{\mathrm{r}}$ の CS 面に詨与る垂直成 分であり，内積 $(0,-1 / 2,1 / 2)_{\mathrm{r}}$ 。 $(p, 2 p+q, p+q)_{\mathrm{r}}=-p / 2$ 上り $\alpha=$ $p / 2$ となる。しかし実際の構造では CS 面内に位置する 8 面体相互の反 発効果によって $D_{\mathrm{sp}}$ 值は理想構造 での值よりも大きくなるものと考え られる.この理想構造からの $D_{\mathrm{sp}}$ 值のずれは高指数 CS 相において

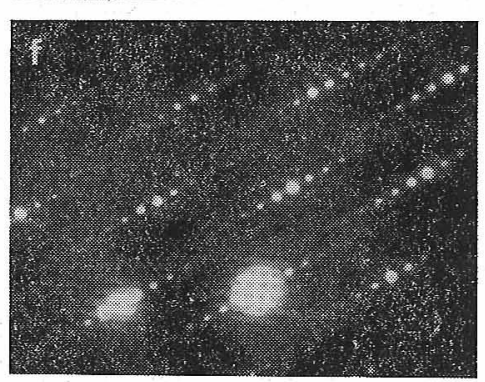
明らかではないので，本研究では (121) $\mathrm{r}$ CS 相の格子定数より求めた $\alpha$ 值 $0.378^{4)}$ と理想樥造での值 0.5

Fig. 2. $[1 \overline{1} 1]_{\mathrm{r}}$ zone axis diffraction patterns for various highindex CS phases. (a) (121) $\mathrm{r}$ CS, $p^{\prime}=$ $\infty, D_{\mathrm{sp}}=12.9 \AA$, (b) $(13,27,14)_{\mathrm{r}}$ CS, $p^{\prime}=13.0, \quad D_{\mathrm{sp}}=12.9 \AA ，(\mathrm{c})$ $(9,19,10)_{\mathrm{r}} \mathrm{CS}, p^{\prime}=9.0, D_{\mathrm{sp}}=13.1$ $\AA$, (d) $(8,17,9)_{\mathrm{r}} \mathrm{CS}, p^{\prime}=8.0, D_{\mathrm{sp}}$ $=13.5 \AA$, (e) $(6,13,7)_{\text {I }} \mathrm{CS}, p^{\prime}==$ $6.0, D_{\mathrm{sp}}=16.7 \AA$, (f) $(3,7,4)$. $\mathrm{CS}_{\text {, }}$ $p^{\prime}=3.0, D_{\mathrm{sp}}=17.9 \AA$, (g) $(5,12$, 7) $\mathrm{r} C, p^{\prime}=2.5, \quad D_{\mathrm{sp}}=18.2 \AA$, (h) Rutile. 
との比 0.756 を高指数 CS 相に 適用し， $D_{\mathrm{sp}}=d_{h k l_{\mathrm{r}}} \times(n-p / 2 \times$ 0.756) とした。したがって $n=$ $D_{\mathrm{sp}} / d_{k h l_{\mathrm{r}}}+p / 2 \times 0.756$ となるの で，実測した $D_{\mathrm{sp}}$ 值より $n$ 值 を見積むることが可能である。

\section{3. 結果及び考察}

\section{1 観 察}

図 2 は $1390^{\circ} \mathrm{C}$ で加熱後, 急冷 した試料より得られた高指数 CS 相の $[1111]_{\mathrm{r}}$ 電子線回折像の例责 示したものである，超格子スポッ 卜の配列は（a）に示した $g\left(121_{\mathrm{r}}\right)$ より (b) $g\left(13,27,14_{\mathrm{r}}\right)$, (c) $g$ $\left(9,19,10_{r}\right),\left(\right.$ d) $g\left(8,17,9_{r}\right),(e)$ $g\left(6,13,7_{\mathrm{x}}\right)$ (f) $g\left(3,7,4_{\mathrm{r}}\right)$ 安経 て (g) $g\left(5,12,7_{\mathrm{r}}\right)$ に沿った方 向一と変化している。すなわち $\mathrm{Cr}_{2} \mathrm{O}_{3}$ 量の娍少に伴い $\mathrm{CS}$ 面の方 位任 $(121)_{\mathrm{r}}$ 加ら $(5,12,7)_{\mathrm{r}}$ 一と 変化し，またCS 面の間隔は 12.9 $\AA$ から $18.2 \AA$ 几と増加した。 Philp ら泣 $1300^{\circ} \mathrm{C}$ において CS 面が $(121)_{\mathrm{r}}$ より $(253)_{\mathrm{r}}$ まで変
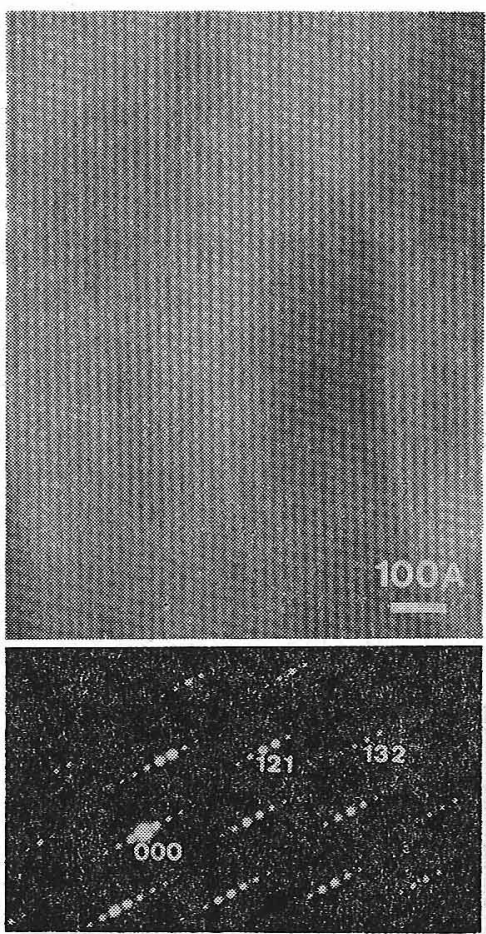

(a)
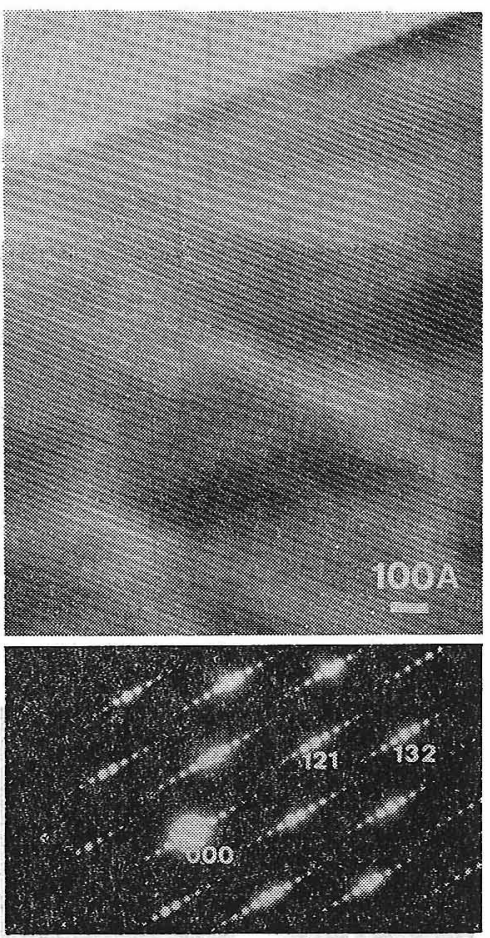

(b)

Fig. 3. Typical lattice images for high-index CS phases and corresponding $[1 \overline{1} 1]_{\mathrm{x}}$ zone axis diffraction patterns, (a) $p^{\prime}=2.7$, $D_{\mathrm{sp}}=18.2 \AA$ and (b) $p^{\prime}=2.5, D_{\mathrm{sp}}=20.7 \AA$. Indices refer to rutile subcell.

化することを報告したが，本研究

では $1390^{\circ} \mathrm{C}$ で調製した試料中に $p^{\prime}=2.0$ すなわち (253) ${ }_{r}$ CS 相は検出されず， $p^{\prime}$ の最小值は 2.5 であっ た. 学た $(5,12,7){ }_{\mathrm{r}} \mathrm{CS}$ 相诘 $\mathrm{Cr}_{2} \mathrm{O}_{3} 7.5 \sim 13.7 \mathrm{wt} \%$ 組 成領域ではルチル固溶体と共存していた。したがって高 指数 CS 相の存在領域，言い換えれば CS 面の回転する

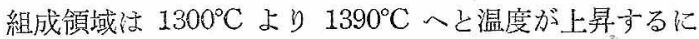
つれて縮小することが朝らかとなった。これは著者らが 既に明らかにした視関係の $\mathrm{TiO}_{2}$ に富んだ組成領域で, $\mathrm{Cr}_{2} \mathrm{O}_{3}$ 量が減少子るにつれてルチル相の出現する境界線 方，温度の上昇に判 $\mathrm{Cr}_{2} \mathrm{O}_{3}$ 側へとずれる傾向と一致 している.また従来，X線的にその存在が考えられてい た $n=9$ の (121) I $\mathrm{CS}$ 相，すなわち $\mathrm{Cr}_{2} \mathrm{Ti}_{7} \mathrm{O}_{17}{ }^{11}$ は， $1390^{\circ} \mathrm{C}$ で加熱，急冷した試料中には認められなかった。 したがって， $1300^{\circ} \mathrm{C}$ に晾ける Philp らの結果と同様 に， $1390^{\circ} \mathrm{C}$ に㧤いて $(121)_{x} \mathrm{CS}$ 相の上端成分は $n=$ 8，すなおち $\mathrm{Cr}_{2} \mathrm{Ti}_{6} \mathrm{O}_{15}$ であると結諭できる. Philp ら は $\mathrm{Cr}_{2} \mathrm{O}_{3} 21.4 \mathrm{w} \%$ （ $\approx \mathrm{Cr}_{2} \mathrm{O}_{3} \cdot 7 \mathrm{TiO}_{2}$ ）組成試料を 1300 ${ }^{\circ} \mathrm{C}$ で加熱後，15 時間で空温までゆっくりと冷却した試 料中に $n=8,9,10$ の (121) $\mathrm{r} \operatorname{CS}$ 相が検出されたと報 告している。これまで $1250^{\circ} \mathrm{C}$ 以下における相関係は明 らかにさ礼ていないので, Philp らのこうした埌告は， $n \geqq 9$ (121) $\mathrm{r}$ CS 相が $1250^{\circ} \mathrm{C}$ 以下で平衡相として存
在しうることを示唆するもので, $\mathrm{Cr}_{2} \mathrm{O}_{3}-\mathrm{TiO}_{2}$ 系の低温 領域沈おける相関係を理解する上で重要と思われる.

表 1 は $\mathrm{Cr}_{2} \mathrm{O}_{3} 13.7 \mathrm{wt} \%$ 組成試料から検出された高指 数 CS 相をまとめたものであるが， $p^{\prime}$ 及び $D_{\mathrm{sp}}$ 值法観 察した個々の結晶片によってわずかずっ異なり，通常単 一の CS 相からなる均質なバルク試料を得ること注困難 であった．しかしながら，各結晶片は図るに示したよう に観察視野内でほ添等閒隔に配列した CS 面からなる格 子像を与えていること，また得られた電子線回折像のス ポットは一般比鮮明であったことから，個々の結晶片は 均質な構造を有するものと考えられる. したがってバル ク試料が不均質であったのは，わずかに異なる構造を有 する高指数 CS 相の組成差が極的て小さいために, 生成 相に微小编析が生じたか，要るい注粒界を通しての陽イ オンの拡散が, 個々の粓内での構造の秩序化よりる相詨 的に遅いためと考えられる. 更に長時間の加熱処理に伴 う微構造の変化を観察することによってこの点は明らか になるであるう。

$\mathrm{Cr}_{2} \mathrm{O}_{3}$ 13.7 24.1 wt\% 組成領域には図 2 に示したほ かに更に多くの高指数 CS 相が検出されたが，それらの 構造は組成とともに変化し，いわゆる2相共存領域は認 められなかった。したがってこれらの高指数 CS 相は， 
Table 1. High-index CS phases detected in the specimen with the composition of $13.7 \mathrm{Cr}_{2} \mathrm{O}_{3}$ wt $\%$ heated at $1390^{\circ} \mathrm{C}$ for $24 \mathrm{~h}$.

\begin{tabular}{llrllc}
\hline $\begin{array}{c}p^{\prime} \\
\text { (obs.) }\end{array}$ & $\begin{array}{c}\mathrm{p}_{\mathrm{sp}} \\
\text { (obs.) }\end{array}$ & \multicolumn{2}{c}{ (fit) $^{\mathrm{q}}$} & $(\mathrm{h}, \mathrm{k}, 1)_{\mathrm{r}}$ & $\begin{array}{c}\mathrm{n} \\
\text { (assigned) }\end{array}$ \\
\hline 2.8 & $18.16 \mathrm{~A}$ & 14 & 5 & $(14,33,19)$ & 189 \\
2.5 & 17.83 & 5 & 2 & $(5,12,7)$ & 68 \\
2.5 & 18.03 & 5 & 2 & $(5,12,7)$ & 68 \\
3.2 & 18.27 & 16 & 5 & $(16,37,21)$ & 231 \\
2.7 & 18.10 & 19 & 7 & $(19,45,26)$ & 257 \\
3.1 & 18.15 & 3 & 1 & $(3,7,4)$ & 40 \\
2.9 & 17.65 & 3 & 1 & $(3,7,4)$ & 39 \\
3.0 & 17.94 & 3 & 1 & $(3,7,4)$ & 40 \\
2.6 & 17.95 & 13 & 5 & $(13,31,18)$ & 176 \\
\hline
\end{tabular}

ある組成に対応した唯一の構造を有するものと考えら れ, Andersonの提唱した “組成適応型構造”(2) (Infinitely adaptive structures) ${ }^{13)}$ を示す一つの具体例であると思 われる、本研究では，均質なバルク試料を得ることはで きなかったが，もし組成の異なる多くの単結晶を合成 し，化学分析によってそれらの組成が決められ，かつ電 子顕微鏡による試料の均質性が確認されるならば, 各組 成に対応した最も安定な高指数 CS 相が決定できるはず であり，更に CS 面の方位と間隔が組成に対していかな る関係にあるかを明らかにすることが可能であろら。し かしながら， $\mathrm{Cr}_{2} \mathrm{O}_{3}-\mathrm{TiO}_{2}$ 系のような 3 元系において， $\mathrm{Ti}-\mathrm{O}$ 系あるいは $\mathrm{V}-\mathrm{O}$ 系と同様の制御された条件下で 単結晶を得た報告はなく，今後の研究が望まれる.

\section{$3.2(5,12,7)_{\text {× }} \mathrm{CS}$ 面の構造モデル}

ルチル構造に対する幾何学的な結晶学的シェア操作は Bursill ら ${ }^{8}$ によって示されている. すなわち，ルチル構 造において酸素面を引きぬくことなく単に母格子を $1 / 2$ [011] r だけ互いにずらすと (011) r 反位相境界面 (Antiphase boundary) が生成し，また（121）r 面に沿って酸 素面を引きぬき, 次に生じた酸素面の間げきを埋めるた めに同様に母格子を $1 / 2[0 \overline{1} 1]_{\mathrm{r}}$ ずらすことによって (121) r CS 面が生成する ．図 4 はルチルの $(100)_{\mathrm{r}}$ 層を 例にとり，(011) r 反位相境界面及び（121） $\mathrm{r}$ CS 面を示 したものであるが，これらに対して同一の原子面を $1 / 2$ $[1 \overline{1} 1]_{\mathrm{r}}$ 変位させて積み重ねることによって 3 次元的な (011) r 反位相境界面及び（121） r CS 面が構成される。

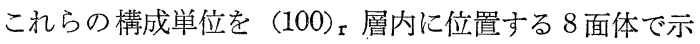
すと, 図 5 のように, $(121)_{\mathrm{r}} \mathrm{CS}$ 面の構成単位は $(011)_{\mathrm{r}}$ 反位相境界面の構成単位に更に 8 面体を一つ加えたもの となっている.ここで図 5 (a) 及び (b) の各構成単位を それぞれ（）及び（ $\triangle$ ) で記号化するならば， $(5,12$ ， 7) $\mathrm{r}$ CS 面の指数は $(5,12,7)_{\mathrm{r}}=5(121)_{\mathrm{r}}+2(011)_{\mathrm{r}}$ で与 えられるのでその構造は 5 個の ( $\triangle$ ）と 2 個の（）の

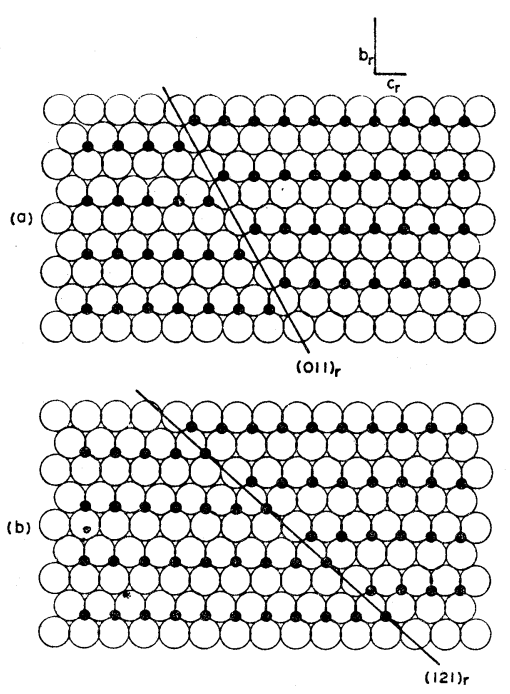

Fig. 4. Structural models of (a) (011) $\mathrm{r}$ APB and (b) (121) $\mathrm{r}$ CS plane on (100) $\mathrm{r}$ layer.

(a)

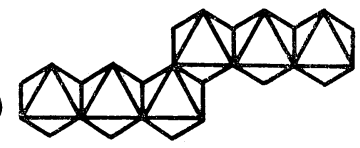

(b)

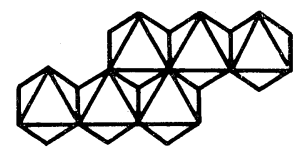

Fig. 5. (a) Structural unit for $(011)_{\mathrm{r}}$ $A P B$ in $(100)_{r}$ plane. (b) Structural unit for $(121)_{\mathrm{r}}$ CS plane in $(100)_{\mathrm{r}}$ plane.

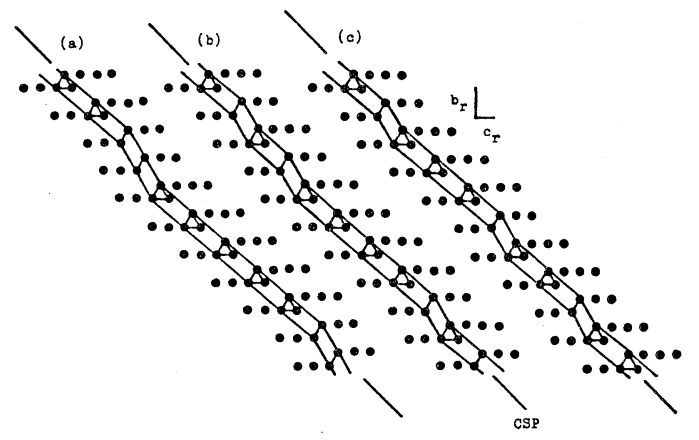

(в) $\Delta \Delta / / \Delta \Delta \Delta \Delta \Delta / / \Delta \Delta \Delta$

(b) $\Delta / \Delta / \Delta \Delta \Delta \Delta / \Delta / \Delta \Delta \Delta$

(c) $\Delta / \Delta \Delta \Delta / \Delta \Delta / \Delta \Delta \Delta / \Delta$

Fig. 6. Three possible arrangements of (121) $\mathrm{r}$ CS and (011) r APB structural units along $(5,12,7)_{\mathrm{r}} \mathrm{CS}$ plane on $(100)_{\mathrm{r}}$ layer showing only metal positions.

繰り返しになると考えられる。したがって $(5,12,7)_{\mathrm{r}} \mathrm{CS}$ 面に対して $(\triangle)$ と（）の三つの可能な配列様式を (100) $\mathrm{r}$ 層内に位置する金属のみで表示すると図 6 のよ 


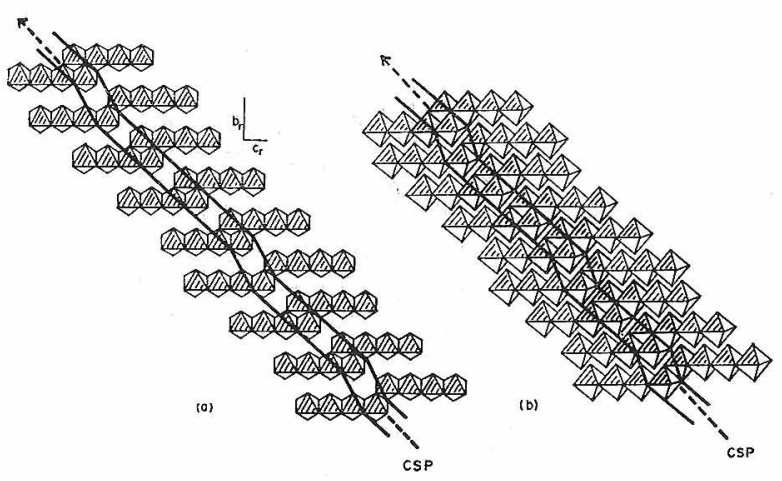

Fig. 7. Structural models for $(5,12,7)_{\mathbf{r}}$ CS plane shown by octahedra in $(100)_{r}$ layer which are projected along (a) $[100]_{\mathrm{r}}$ and (b) $[1 \overline{1} 1]_{\mathrm{r}}$ directions.
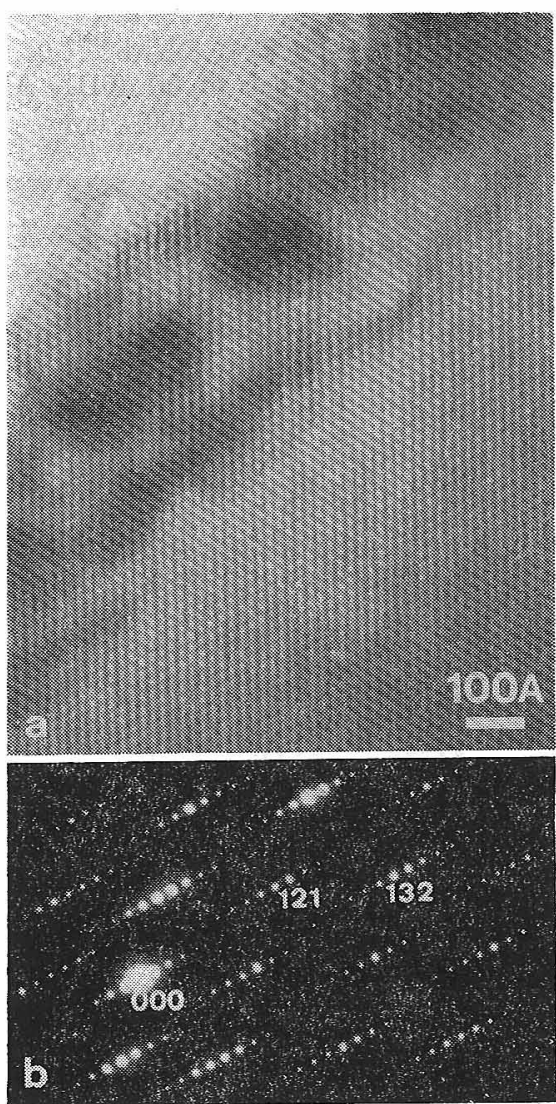

Fig. 8. (a) Lattice image of $(5,12,7)_{\mathrm{r}} \mathrm{CS}$ phase with $D_{\text {sp }}=18.2 \AA$ suggesting waving features along CS planes. (b) Corresponding $[1 \overline{1} 1]_{\mathrm{r}}$ zone axis diffraction pattern. Indices refer to rutile-subcell.

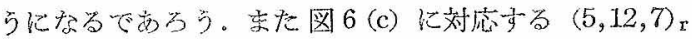
$\mathrm{CS}$ 面の棰造モデルを [100] $\mathrm{r}$ 及び [111] $\mathrm{x}$ 方向上り投 影寸ると図7に㽽る。これらの構造モデルに従えば，

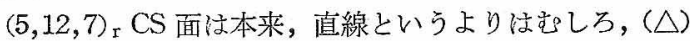

と（ノ）の配列様式によって折れ曲がった構造にな るであろう。図 8 に示した格子像写真に剠て, 結 晶片のエッジ近傍には試料を砕いた際に生じたと思 われる損傷が認められるが，損傷を受けていない領 域を詳細に観察すると，ら水った CS 面が見られ る。これは $(5,12,7)_{\mathrm{r}} \mathrm{CS}$ 面の折れ曲がった構造モ デルに対忍するものと考えられる。 また構成単位

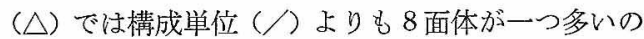
で，定性的に考えれば，( $\triangle$ ）内での 8 面体相互の 反発力は（）内よりも大きいであるう。したがっ

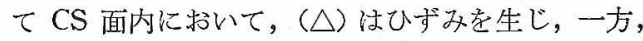
（）はそのひずみを緩和するように作用するもの と考えられるので, 図6の三つの構造モデルのう

ち，(メ）と（ が CS 面に沿ってより均等に配 列した (c) が最も安定な構造に対応すると思われる。図 8 の格子像では，分解能の限界から CS 面に沿った

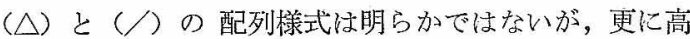
分解能の格子像観察を行えば， $(5,12,7)_{x}$ CS 面に対し て図 6 (c) の構造モデルが適用できるか不か判断できる であろう。

\section{4. 総 括}

$\mathrm{Cr}_{2} \mathrm{O}_{3}$ 7.5 24.1 wt\% の組成試料を $1390^{\circ} \mathrm{C}$ で加熱, 急冷した後，透過型電子顕微鏡で観察した結果，以下の 知見索得た。

(1) $\mathrm{Cr}_{2} \mathrm{O}_{3}$ 13.7 24.1 wt \% 組成領域に抒いて，高 指数 $\mathrm{CS}$ 相の CS 面の方位は $\mathrm{Cr}_{2} \mathrm{O}_{3}$ 量功減少打るにつ れて $(121)_{\mathrm{r}}$ より $(5,12,7)_{\mathrm{r}}$ まで変化し, それに伴い CS 面の閒隔は $12.9 \AA$ より $18.2 \AA$ 几と増加した。

(2) $(5,12,7)_{\mathrm{r}} \mathrm{CS}$ 相は $\mathrm{Cr}_{2} \mathrm{O}_{3} 7.5 \sim 13.7 \mathrm{wt} \%$ に市 いて，ルチル固溶体と共存し，また $(121)_{\mathrm{r}} \mathrm{CS}$ 相の上 端成分は $n=8$ ，すなわち $\mathrm{Cr}_{2} \mathrm{Ti}_{6} \mathrm{O}_{15}$ であった。

（3）一定組成試料中の個々の結晶片によって，わず かずつ異なる構造をもった CS 相が検出され，均質なバ ルク試料を得ることは困難であったが，個々の結晶片は 等間隔に配列する CS 面からなる均質な構造を有してい t.

（4）高指数 CS 面は直線状というよりはむしろ, (011) r 及び $(121)_{\mathrm{r}}$ の各構成単位の配列様式によって, 折れ曲がった構造であることが示昖された。

謝 辞 名古屋大学 工学部 平野真一助教授並びに東京工 業大学 工学部 長倉繁麿教授には有益な助言を賜ったので謝意 美表します。

\section{文献}

1) K. Anzai, S. Hirano and S. Sōmiya, Bull. Tokyo Inst. Tech., No. 120, 35-55 (1974).

2) S. Sömiya, S. Hirano and S. Kamiya, J. Solid State 
Chem., 25, 273-84 (1978).

3) S. Sōmiya, M. Yoshimura, S. Kamiya and S. Itoh, Science of Ceramics 10, in press (1980).

4) S. Kamiya, M. Yoshimura and S. Sōmiya, Mater. Res. Bull., 15, 1303-12 (1980).

5) R.M. Gibb and J.S. Anderson, J. Solid State Chem., 4, 379-90 (1972).

6) D.K. Philp and L.A. Bursill, J. Solid State Chem., 10, 357-70 (1974).

7) L.A. Bursill, B.G. Hyde and D.K. Philp, Phil. Mag., 23, 1501-13 (1971).

8) L.A. Bursill and B.G. Hyde, Prog. Solid State Chem.,
Vol. 7, ed. by Reiss and J.O. McCaldin (1972) p. 177-253.

9) L.A. Bursill, N.B.S. Special Publication 364, Solid State Chem., Proceeding of 5th Materials Research Symposium, 727-43 (1972).

10) J.R. Gannon and R.J.D. Tilley, J. Microsc., 106, 59-61 (1975).

11) S. Andersson, A. Sundholm and A. Magnéli, Acta Chem. Scand., 13, 989-97 (1959).

12) 森本信男, 化学, 29, 392-96 (1974).

13) J.S. Anderson, J. Chem. Soc. Dalton, 1107-15 (1973).

論 文・Paper

\title{
凍結乾燥硫酸塩の熱分解によるスピネル $\left(\mathrm{MgAl}_{2} \mathrm{O}_{4}\right)$ の生成過程
}

\author{
服 部 豪 夫・毛 利 純一 \\ (千葉大学 工学部 工業化学科)
}

\begin{abstract}
易焼結性微粉末調製法の一つとして凍結乾燥法が試みられ, 興味ある結果が報告されている. 本 報告はスピネル組成比の硫酸マグネシウム水溶液と硫酸アルミニウム水溶液の混合溶液を凍結乾燥 し, 得られた塩の熱分解举動を DTA, TG, 及びX線回折法により検討したものである. その結 果, 混合水溶液の 凍結乾燥塩沙非晶質の $\mathrm{MgSO}_{4} \cdot 6 \mathrm{H}_{2} \mathrm{O}$ と結晶質の $\mathrm{Al}_{2}\left(\mathrm{SO}_{4}\right)_{3} \cdot 17 \mathrm{H}_{2} \mathrm{O}$ の混合物 であると考えられた．この凍結塩を加熱すると, 結晶性の硫酸アルミニウム 17 水塩は結晶性無水 硫酸塩を経たのち, 非晶質のアルミナを生成した. 一方, 非晶質の硫酸マグネシウム 6 水塩は非晶 質の無水塩となり，その後いったん結晶化したのち分解し，非晶質のマグネシアを生成した．この 非晶質マグネシアの一部はそのとき既に生成していた非晶質のアルミナと直ちに反応してスピネル を生成させた. このとき反応しなかったマグネシアはその後結晶化したが，それがアルミナと反応 しスピネルを生成させるのには更に高温を要した，以上のようにスピネルの生成は低温での生成と 高温での生成という 2 段階の生成過程から成っていることが分った.

(1980 年 7 月 23 日受付)
\end{abstract}

\section{Formation Processes of Spinel $\left(\mathrm{MgAl}_{2} \mathrm{O}_{4}\right)$ by a Thermal Decomposition of a Freeze-Dried Sulfate}

\author{
Takeo HATTORI and Jun-ichi MOHRI \\ (Department of Industrial Chemistry, Faculty of Engineering, Chiba University) \\ 1-33, Yayoi-cho, Chiba-shi 260
}

The freeze-dried salt was prepared from the mixed solution of magnesium and aluminum sulfates in composition of spinel. The thermal decomposition processes of the resultant salt were studied with DTA, TG and X-ray powder diffraction methods, and the formation processes of spinel were discussed.

The results obtaind were as follows:

(1) The salt seemed to be composed of the mixture of two compounds of $\mathrm{MgSO}_{4} \cdot 6 \mathrm{H}_{2} \mathrm{O}$ and $\mathrm{Al}_{2}\left(\mathrm{SO}_{4}\right)_{3} \cdot 17 \mathrm{H}_{2} \mathrm{O}$, in which magnesium sulfate was amorphous and aluminum sulfate crystalline.

(2) On heating the freeze-dried salt, the crystalline $\mathrm{Al}_{2}\left(\mathrm{SO}_{4}\right)_{3} \cdot 17 \mathrm{H}_{2} \mathrm{O}$ decomposed to a 